\title{
The looting during the social upsurge of October 2019 in Chile
}

\author{
EDISON CARRASCO JIMÉNEZ ${ }^{1}$ \\ ${ }^{1}$ Facultad de Derecho, Universidad de las Américas, Santiago — Chile
}

\section{KEYWORDS}

disaster criminology, disaster studies, looting, social upsurge Chile 2019

\begin{abstract}
Since the social explosion in October 2019 in Chile, a series of social phenomena have occurred in that country that are worthy of review and study. Some of these phenomena have antisocial/criminal characteristics. Within these phenomena, looting is one of them. These took place from the first moments of the social outburst. The objective of this research is to study the criminal phenomenon of looting during the social explosion of October 2019 and throughout that period. But in addition, and because they are similar social phenomena and occurred in the same geographical-human space (Chile) and in periods not so distant in time, the looting that took place during the earthquake of February 27th, 2010 (27/F) in Chile will be the object of investigation. Our theoretical option to study this criminal phenomenon will be the so-called Disaster Studies, and in particular, from what we could call a disaster criminology. We will use not only the specialized literature on disasters, but also the academic works related to the earthquake of February $27^{\text {th }}$ and the journalistic literature related to the looting during the earthquake of 27/F as well as that related to the social explosion of October 2019.
\end{abstract}

\section{Correspondence}

Email: ecarrasco@udla.cl

\section{ACKNOWLEDGMENTS}

We thank the University of the Americas, Chile, and in the person of its Director of Research Mr. Hernán Cañón, for all the material assistance provided for the achievement of this research. Special mention is given to the Dean of the Faculty of Law, Mr. Marco Vega López, for his material and personal help, and for his initiative to promote legal and criminological research in the Faculty of Law, which has made it possible to reach port with the ideas expressed in this text. 


\section{1 | INTRODUCTION}

The social explosion or "blowout" in Chile (Salazar, 2019) that arose with the protests of October 18, 2018 (18/O from here on), constituted of both spontaneous and organized actions that range from fires and confrontation with police forces to "cacerolazos" -noisy-subject (Ozguc, 2019) and regional charivari, as the hallmark of Chilean urban protest (Ruiz, 2019) have produced some perplexity in the Chilean political class, although perhaps from the deepest social observation it has not been a surprise.

There was a whole symptomatologic picture that envisioned the future: the student movements of 2001, 2006 and 2011, the abstention in the 2016 votes (Carrasco-Jiménez, 2016), the constant burning of private property in the so-called "Araucanía zone" in southern Chile, the sustained popular criticism and the protests for the Chilean social security system and the health system (Elm, Madrid, \& Urrútia, 2019; Fraser, 2019). From a Lacanian point of view were only hindrances to the expression/comprehension of meaning (Lacan, 2005), and for that reason the political measures adopted by the administrations of the "Concertación (Nueva Mayoría)" governments and the right-wing coalition with Piñera at the head, were not able to decode the sign after the symptom. On the contrary, the government administration of the second government of Piñera (2018) constantly challenged with repressive instruments the popular demonstrations of rejection of the pension system, the health system, and the measures of price increases that were announced in October 2019, to which were added the communicational errors of the Piñera administration that caused discomfort (Rovira Kaltwasser, 2019) and that were understood as lack of respect, and any lack of respect produces an effect of rejection and deterioration of the political relationship (Eschert \& Simon, 2019).

So far, there are no known studies that analyze the situation in comment, probably because of the proximity of the facts, and also because of their latency. One of the phenomena that took place during the social outburst and that has lasted over time along with the civil unrest, has been looting. This article attempts to analyse this phenomenon.

Basically, the approach to the problem will be made from the so-called disaster studies (E. Quarantelli \& Dynes, 1977), and that by studying an antisocial phenomenon of a criminal nature, it could be understood that it is observed from criminology, picking up the demand of literature to be that which calls for the understanding of antisocial/criminal behaviour during the disaster (Frailing \& Harper, 2017).

We will also analyse the looting produced in the earthquake/tsunami in Chile on February 27, 2010, which mainly affected the current regions of Bío-Bío, Ñuble, Maule, and Libertador Bernardo O'Higgins, in order to establish a comparison with the looting of the social explosion of October 2019.

The analysis will extend to these facts, because they are a phenomenon of disaster similar to that of the social outburst of October 2019, because they occur in the same geographic-human space (Chile), within a relatively close period of time ( 9 years of difference), and under a similar government administration as was that of Sebastián Piñera although in different periods of government (first period of government: 2010-2014; second period of government: 2018-2021; second period of government: 2018-2021), although in different periods of government (first period of government: 2010-2014; second period of government: 2018-2021).

Not only scientific literature will be used, but also journalistic literature, especially so-called investigative journalism, which throws a lot of light on a phenomenon still in development, especially because they contain elements for qualitative analysis, such as testimonies, attitudes, opinions, and so on. Thus we will have to approach the phenomenon according to the first and third meaning of "observation" proposed by Peretz (2014), that is, social observation through 
the collection of all types of data and ethnographic observation (Peretz, 2014). The same and particularly the fourth meaning proposed by the author concurs, that is, to be involved in a social situation without modifying it, by virtue that the author of the text has taken knowledge of the facts in situ, by having found in both places of observation during each one of the episodes investigated here.

\section{2 | FROM DISASTER STUDIES TO DISASTER CRIMINOLOGY}

Disaster studies are generally a century old, but a Sociology of Disasters (Brown, 2019; Kreps, 2001; E. Quarantelli \& Dynes, 1977) must have a relatively young life of at least fifty years to date, and where its number, compared to other lines of research, is smaller. Even smaller is outside the U.S., where little academic attention has been paid (E. L. Quarantelli, 2008). And those devoted to antisocial behavior in disasters, and specifically to criminals, are even more limited. However, its importance, in our opinion, lies in its specialization, in that the view of the phenomena under study differs because of its macrosocial vision given the characteristics of the disaster of being a socially generalized disturbance, as well as because of the targeting it has for countries with civil disturbances or disasters, and even more so for those in which both occur, since it increases the probability of generalization due to the presence of equivalence in some factors.

The disaster has serious defining complications, as has been highlighted by the literature (Perry, 2007). Aguirre and Lane (2019) define it as "sudden shifts of sociocultural complexes that may be co-present in social subsystems impacted by hazards, with very often distinct and dissimilar temporal patterns" (Aguirre \& Lane, 2019, p. 77). Perry (2007) prefers to indicate common elements that social science describes for disasters: a) that it is a social phenomenon; b) that it produces a social disruption; c) that take place on the occasion of social vulnerability; d) that it constitutes a failure of the normative and cultural system; e) that resilience phenomena are produced. Within this universe, studies of disasters tend to distinguish between civil disturbances and disasters (as such) (Aguirre \& Lane, 2019; Brown, 2019; E. Quarantelli \& Dynes, 1968, 1977), a distinction that we will maintain in this research for practical reasons, with some additional conceptual precision. Both prosocial behaviors (therapeutic community, resilience) (Espinoza, Osorio-Parraguez, \& Posada Quiroga, 2019; Harrison \& Williams, 2016; Kaniasty, 2020; Moreno \& Shaw, 2019; Phillips, 2015; Silver \& Grek-Martin, 2015; Tidball \& Aktipis, 2018) and antisocial have been studied. Within the latter are criminal behaviors, and here the spectrum opens from looting and destruction of property to white-collar crimes and corruption (Aguirre \& Lane, 2019; Gallego, 2018; Imperiale \& Vanclay, 2019). These studies would already be walking the path of a criminology of disaster. From the studies that have dealt with looting and destruction, it can be inferred that it would be necessary to distinguish those related to the looting/destruction of cultural objects (Hammer, Seifried, Franklin, \& Lauricella, 2018; Johnson, 2005; Kinkopf \& Beck, 2016; Tapete, Cigna, \& Donoghue, 2016), economic or financial looting (Black, 2005; Cull, Matesova, \& Shirley, 2002; Mueller, 2003; Pizzo, Fricker, \& Muolo, 2015), and looting in civil disturbances. It has been understood that looting in particular has received little academic attention (Mac Ginty, 2004). While Azam and Hoeffler define looting as "the appropriation of some of the other group's output, without military opposition" (Azam \& Hoeffler, 2002, p. 136), Mac Ginty defines it as "a specific form of highly situational political violence involving the appropriation of goods, and often occurring in concentrated bursts and against a backdrop of violence or tension" (Mac Ginty, 2004, p. 861). 


\section{3 | LOOTING IN DISASTER STUDIES}

The study by Quarantelli and Dynes (1968) Looting in Civil Disorders: an Index of Social Change, places as a context of study, the riots of 1964, 1965 and 1967 in which various establishments were looted and burned. They express that the common interpretation is to look at them as irrational actions in periods of social disorganization. But contrary to this interpretation, the authors maintain that looting has a direct relation with social change, not inasmuch as that one is an impeller of social change as some studies maintain (Prince, 1920; Sorokin, 2017), but an index of social change, representing a social conflict on the previously shared understanding of what property is. The authors point out that "property is a shared understanding about who can do what with the valued resources within a community" (E. Quarantelli \& Dynes, 1968, p. 8). Legal norms establish the forms of use, control and disposition of property, and the rights and obligations with respect to it, in a given period of time. The looting represents a difference of opinion of that understanding, a collapse of that understanding and that would result in a redefinition of existing property rights.

In addition, they determine that there is a pattern to looting, which has the following characteristics: (a) looting is highly selective, focusing on a certain type of asset as the sole focus: (b) looters receive targeted social support, usually from their own local community; c) looting occurs in stages where, first, looting is minimal and there is greater destruction of symbolic objects from the underlying sources of conflict (police carts, white-owned shops, for example), second, looting is greater and more organized, and destruction tends to be less, third, widespread and non-systematic appropriation, where a "carnival spirit" reigns (E., "carnival"). Quarantelli \& Dynes, 1968, p. 9); d) looting is rarely carried out by solitary individuals, and tends to be carried out in pairs or small groups.

On the other hand, they indicate that authority and the middle classes that preserve the almost sacred conception of private property, see this only as antisocial and delinquent behavior, in the sense of being against the law, antiriot devices and repressive measures are strengthened. And while the authors agree that they are criminal acts, they point out that they conceal something, and that the laws themselves are based on certain dominant conceptions of property rights, residues of past consensus regarding the distribution of property, and that looting and destruction are communicating a message that a moment of social change is approaching, particularly with respect to the distribution of resources considered valuable by the community. "The psychological controls - the authors express - which really are the bases of police control in a community no longer suffice. The sheer power of National Guard or regular military units, when disorders reach a peak, is the only formal control left to communities" (E. Quarantelli \& Dynes, 1968, p. 10).

In later studies, Quarantelli and Dynes $(1969,1970)$ point out that there are two approaches to the phenomenon of looting: an individual and expressive perspective on looting, and a group and instrumental perspective on looting.

The individual and expressive perspective of looting, where looting is described as an individual's behavior and from his or her individual psychological characteristics, which would reflect a criminal tendency to opportunistic theft and where looting would be a symptom of an underlying problem. The looters would have the façade of a civilized man, but with looting unleashes a wild animal, a kind of Dr. Jekyll and Mr. Hyde. If so, social control would be a formal type, and would work by repressing antisocial and criminal behavior, since looting 
would be a deviant behavior that is rooted in man and not in his social conditions (E. L. Quarantelli \& Dynes, 1969, 1970).

According to this position, which the authors call "frustration-aggression thesis" (E. L. Quarantelli \& Dynes, 1970, p. 170), there would also be an expressive purpose in these actions. Looting would be the expression of aggression focused on objects as a result of lasting frustrations, where the subject attacks blindly and gives free rein to his repressed rage (E. L. Quarantelli \& Dynes, 1969, 1970).

There is in this perspective a notion of superficial, incomplete or defective socialization of an individual who deviates absolutely from the existing norms. This posed, from the most sophisticated versions of the individual approach, would have to be alienation and anomie (E. L. Quarantelli \& Dynes, 1969, 1970).

Social isolation implies that they feel unable to control the events of their world, so they are able to perform the most extreme actions. But this last assertion is contradicted by the type of participants in a looting, who are generally socialized people, of the middle class, workers, residents in their neighborhoods, with normalized conducts and very distant to the characteristics of a socially isolated person (E. L. Quarantelli \& Dynes, 1969, 1970).

Nor has it been possible to establish in empirical studies a pattern between relative deprivation and looting (E. L. Quarantelli \& Dynes, 1969, 1970).

For its part, in the group and instrumental perspective of looting, the latter is described as the behavior of a group and for instrumental purposes, where there is no absolute separation of existing rules or deviant behavior, but on the contrary, conformity to a new social norm or expectation, which would be the emerging rules of the group. Social control would only be achieved by creating new institutional patterns that would be the functional equivalent of the existing pattern in the plundering group, institutionalizing group behavior. "The problem viewed in this way - Quarantelli and Dynes point out - thus becomes one of bringing about social change rather than suppressing deviant behavior" (E. L. Quarantelli \& Dynes, 1969, p. 280). In the U.S., the protest and the looting related to them would focus on the existing property right in this country.

To consider that the behavior is similar in looting in a civil disturbance as in natural disasters would be an incorrect assumption. On the contrary, for the authors there are differences between looting in natural disasters and civil unrest: a) while in civil unrest looting is widespread, it rarely occurs in natural disasters; b) while in civil unrest looting is collective, not so in natural disaster where a group of individuals is reduced alone; c) in civil unrest looting occurs in an open manner and in front of passers-by, whereas looting in natural disasters is a private act, occurs secretly and covertly to the observation of others; d) while in civil disturbances looting is selective (grocery stores, furniture, clothes and liquor), in natural disasters it is rather situational; e) while in civil disturbance looting is done by local residents, in natural disasters outsiders participate; f) while in civil unrest looting there is little sanction both before and after the looting, in natural disaster it is sanctioned very severely, and the tone is condemnatory; g) although in both natural disasters and civil disturbances there is a redefinition of the right to property, it occurs in one and the other in a different way, since in the former there will be a consensus on this right, which consists in the fact that in natural disasters property rights are suspended in favour of the common good, and therefore their redefinition is from private to common, whereas in civil disturbance there is dissent, a discussion on the right to property, where looting is an effective sign of communication, which sensitizes the upper classes to the need for reconstruction and social change. Therefore, looting in both cases expresses this consensus and dissent in each of the particular situations, not constituting an 
action in the absence of norm, and therefore, they would not be anomalous situations (E. Quarantelli \& Dynes, 1977; E. L. Quarantelli \& Dynes, 1969, 1970).

For their part, Quarantelli's studies reaffirm the same concepts. He expresses that looting rarely takes place, almost never, in disasters, and if it becomes concrete, it is only verified in things of little value, being in general the constant prosocial behavior and not the antisocial one (E. Quarantelli, 1994). But, and apropos of the situation of the island of St. Croix by the passage of Hurricane "Hugo" in the U.S.A., it seems to open up to another possibility (a "second Quarantelli"). He points out that the prevailing idea and that they consider a "myth", is that looting does not occur in natural disasters, but in riots (E. Quarantelli, 2007) ${ }^{1}$. Quarantelli seems to observe that looting in natural disasters is rarer than in civil unrest, and must occur concomitantly with other social conditions, such as the existence of lawbreakers and the inaction of the police in the face of the fact. This same idea, but better developed, is supported later in Conventional Beliefs and Counterintuitive Realities (2008). He insists on the idea of the differences between looting in riots and in disasters, the latter being smaller than in the former, although more frequent in developing countries, and occurring in disasters only if "a complex set of priorsocial conditions exist" (E. L. Quarantelli, 2008, p. 883), which he calls "necessary conditions", and in addition "a sufficient conditions" (E. L. Quarantelli, 2008, p. 883). These additional sufficient conditions are: a) the existence of disadvantaged people subject to daily perceptions of great differences in lifestyle between them and the rest; b) a subculture tolerant of petty theft, such as organized youth gangs involved in serious crimes such as drug trafficking; c) an inefficient and corrupt local police force. And in terms of general criminality, "all standard criminal behavior rates return to what they were at the time of the impact of the disaster/catastrophe. with future increases following whatever pre-impact trend lines existed" (E. L. Quarantelli, 2008, p. 885).

Brown does not agree that there are differences between disaster and riot when it comes to antisocial behavior in these events, pointing out that there is evidence of looting in disasters as well as in riots, and that both have a similarity, which is that they share an identical motivation to be a complaint as the only way to communicate their claim (Brown, 2019). Looting also occurs because the owners of things leave them vulnerable for fear of violence. Brown expresses that "disasters that happen in places where there are heavy pockets of concentrated poverty, high unemployment rates, low median income and levels of education can also be situations of temporary and localised redefinitions of property rights because of the cumulatively disenfranchised populations and temporary breakdown in social organisation. It is no coincidence that these are the places where instances of police brutality are prevalent, too" (Brown, 2019, p. 3). The disaster produces a fracture in the social structure that gives rise to the expression of anger and complaint against the oppressor about the social inequality in which one lives, be it poverty, unemployment, low income, racism or economic distress. For Brown, disasters only expose the circumstances of social injustice and inequality lived in the place where the looting takes place.

For its part, Mac Ginty (2004) states that looting has had little academic attention as an object of study, so it addresses conceptualizing looting, identifying the necessary precipitating factors and offering a typology of looting. The following scheme sets out what has been said:

\footnotetext{
${ }^{1}$ Identical opinion in Frailing, 2007.
} 


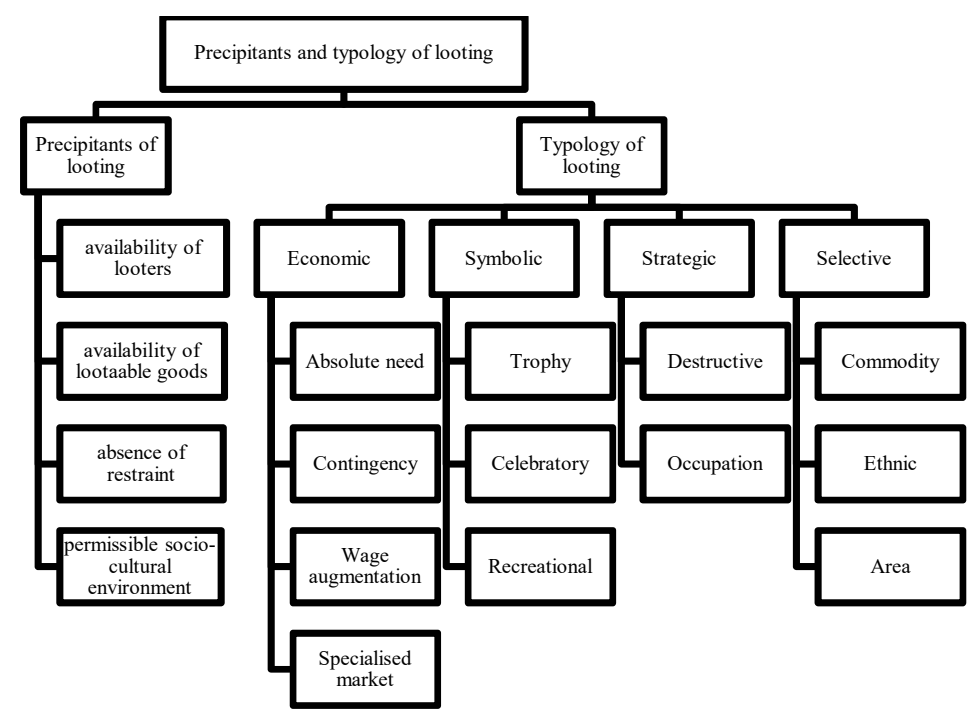

FIGURE 1. Precipitans and typology of looting, Mac Ginty. Source: Own elaboration, from publication Mac Ginty (2004)

Of the "precipitants" both the "availability of looters" and the "availability of lootaable goods", Mac Ginty understands them as obvious, but necessary to consign, because they represent the highly situational character of looting. The "absence of restraint" can be forces of the State, sociocultural norms, limitations of the same object. The category of "permissible socio-cultural environment", supposes that the same positive interpretation of looting is shared cognitively, even for a short time.

Economic looting is equivalent to the greed thesis spoken by Mac Ginty, linked to the idea of looting to satisfy basic needs ("absolute need"), or the opportunistic looting for subsequent sale of goods for their potential commercial value ("contingency"), or the looting of poorly paid civil servants who attempt through wage augmentation, or the looting of antiques or objects of cultural value ("specialised market").In symbolic looting, utility is not material, but is plundered to obtain a trophy, as a way of celebrating an event such as a change in a political regime ("celebratory"), or which may take place some time after a political upheaval without restrictive authority and where looting is socially accepted ("recreational"). Strategic looting may consist of appropriating to destroy property as part of a broader framework of destruction, such as an ethnic purge for example ("destructive"), or it may take possession of objects, denying it to others ("occupation"). Selective looting" can either be selective looting according to products, generally of high value, such as liquor, electronic products ("commodity"), or looting of objects or properties according to ethnicity ("ethnic") or area ("area") according to their identity group (Mac Ginty, 2004).

Other studies have raised more specific and limited questions about looting. Certain causal factors are mentioned in connection with the August 2011 riots in the United Kingdom, such as frustration and lack of opportunities (Bencsik, 2018; Briggs, 2012; Mac Ginty, 2004). Socio-economic factors are also mentioned. Conley and Wang express that unbalanced economic growth or contraction that helps the rich or disproportionately harms the poor can lead to social collapse, including criminal activities such as looting (Conley \& Wang, 2006). Situational variables observed in the production of looting in stores are also mentioned, such as certain contagion effects, for example, if there was a looted store, the probability of looting from other nearby stores increased, or, if there was an armed defense of one store, the probability of 
disincentive to looting in others increased (Muhlin et al., 1981). In this case, however, the socalled "selective looting" could be an exception, requiring premeditation and target discrimination (Mac Ginty, 2004). The factors of lack of electricity, absence of information and slow response of the authority to the emergency would contribute positively to looting in geological disasters such as tidal waves and earthquakes (Bo et al., 2015; Moreno, Lara, \& Torres, 2019; Moreno \& Shaw, 2019).

\section{4 | SYSTEMATIZATION OF CRIMINOLOGICAL STUDIES ON LOOTING}

We may systematize criminological studies of looting, according to their approaches and as follows.

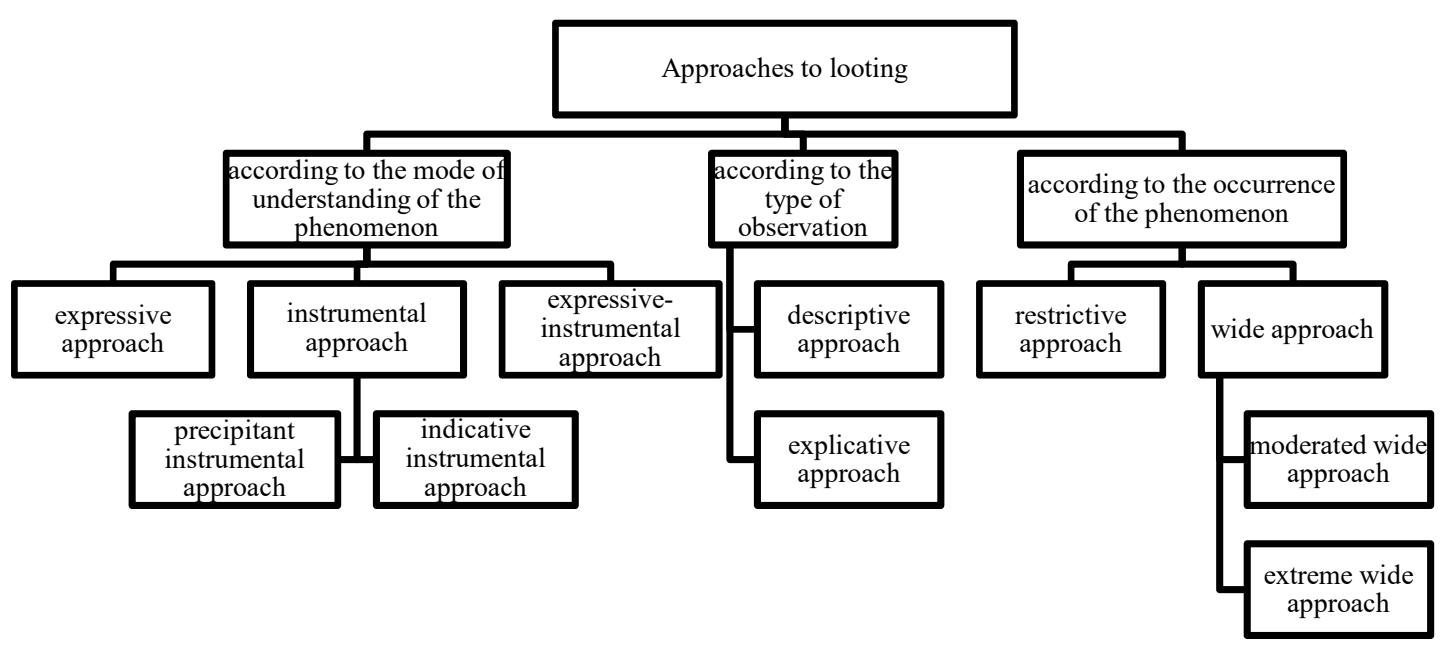

FIGURE 2: Classes of approaches to looting. Source: Own elaboration

The way of understanding the phenomenon would be basically the already revised classification that Quarantelli and Dynes do. The clades that emerge correspond to the visions of looting in relation to social change, whether they understand that it is an instrument to provoke it (precipitating instrumental approach) or as an index to it (indicative instrumental approach). But we add a third vision, that is to say, and as a priority, the expressive-instrumental approach.

But looting is also a phallic expression: an acting-out (Freud, 1968; Lacan, 2004), but of a social character. This is, a certain intrapsychic phenomenon that being individual, becomes common to a social group by sharing the same social experience, and that at the same time, is revealed in a social behavior distorted and shared in the same way, whose moment of appearance and social manifestation arises when a social disruption occurs. It has many similarities with the analysis of kleptomania and its relation to Lacan's acting-out, who expresses that the object removed by force or cunning by the kleptomaniac is due to the fact that in another place there is another object, which is his (Lacan, 2004), with which it denotes a fault. But in this case, the individual intrapsychic meaning is replaced by a social one, by the social character of its expression: the unconscious revelation of its absence within the social contract, and therefore, the feeling of exclusion of the current juridical status of the property. That is why Quarantelli and Dynes pointed out that looting could be executed (in the analysis of African-American civil disturbances) by people who did not have feelings of aggressiveness, 
and because of that, they excluded expressiveness (E. L. Quarantelli \& Dynes, 1969, 1970). But expressiveness also implies unconsciousness, and acting-out without a direct explanation based on the signifying/significant relationship. The looting in civil disturbances would be, at best, the expression of a kleptomaniac act in mass, precipitated by the social disruption implied by the civil disturbance, and proportionally equivalent in social energy to that of the civil disturbance. This should be for us, the expressive-instrumental approach, which is what we adopt.

For its part, depending on the type of observation, the descriptive approach focuses on studying the phenomenon of looting, in detailing its characteristics and particularities. Mac Ginty's "typology of looting" would belong, under this criterion, to a descriptive approach, because it consists of a classification of the characteristics of looting according to its use and according to situational criteria. On the other hand, an explanatory approach would attempt to explain the factors of looting, both the situational factors that give rise to looting (Mac Ginty's "precipitants"), and the exotic factors, that is, the individual or social psychological factors and the structural factors that give rise to looting.

According to the occurrence of looting, a restrictive approach would consider that looting occurs only in civil unrest, and is practically non-existent in natural disasters, or occurs very rarely (the "first" Quarantelli or pre-Hurricane "Hugo"). A broad approach, on the other hand, would consider that looting occurs in both cases, with an extreme broad approach comprising the same occurrence of looting in the two situations without distinction (Brown, for example), as opposed to a moderate broad approach, which would consider that, although in both cases looting can occur, in disasters it has less occurrence and as long as there are circumstances such as problems of social inequality (the "second" Quarantelli or post-Hurricane "Hugo").

5 | THE LOOTING IN THE NATURAL DISASTER OF THE EARTHQUAKE OF THE 27/F 2010 AND IN THE CIVIL RIOTS OF THE SOCIAL EXPLOSION OF OCTOBER IN CHILE

\section{1 | LOOTING IN THE EARTHQUAKE OF 27/F 2010 ACCORDING TO THE SOCIOLOGY OF THE CHILEAN DISASTER AND ACCORDING TO THE JOURNALISTIC NARRATIVE}

As a result of the earthquake/tsunami of February 27, 2010 (27/F), several looting occurred in the country, affecting, in turn, several commercial places, such as supermarkets, pharmacies, service stations, restaurants, food warehouses, banks and ATMs, large stores (such as "La Polar" in Concepción), warehouses and small shops, but never rooms at home (Alarcón Corsi, 2010; González-Muzzio, 2013, 2013; Grandón F. et al.., 2014; Guzmán, 2010b; Leal, 2013; Sanzana Calvet, 2010; Warren, 2010). At first they were necessities due to water shortages (Bustamante, 2010), but then they were totally different: "it would have been mainly about looting," says González-Muzzio, "since it happened during the first hours and days following the earthquake, when there was no urgent "need" to appropriate food or other supplies, or to obtain televisions, washing machines or other items that are not "necessities" (González-Muzzio, 2013, p. 32). A witness to the fact expressed, "I saw burlesque glances, people who were happily pushing a car loaded with liquor or meat, enjoying their good luck" (Guzmán, 2010a). The explanations of the looters who were later accused and even convicted of 
theft on the motive of the looting was, "It's like they were all stealing" (Guzmán, 2010a). The looters were not delinquents, nor did they have previous records, belonging to different groups or social classes, located in the place where the looting took place. There were also organized gangs, but their contribution was not nuclear (Guzmán, 2010a).

The looting was not approved by the general community, which was seen as unnecessary, morally reprehensible and aesthetically negative (Guzmán, 2010b; BBC World News, 2010; Roca, 2016) ${ }^{2}$.There would have been organized groups for looting, a few minutes before the earthquake, mobilized in buses and carrying firearms, belonging to low-income sectors, which were joined by people from different social strata, even high income. Those who acted this way justified themselves in the perception of the lack of supply (González-Muzzio, 2013).

Baeza (2010) presents six theses that should be antecedents or "causes" of the acts of looting. The first thesis argues that there would have been an ideological context in which the earthquake took place, characterized by a destruction of the social fabric, the egocentric search for success and material possession, "a kind of individualistic and narcissistic withdrawal accompanied by a curious imaginary of disregarding the social" (Baeza, 2010, p. 57), a social atomization and a "frantic consumerism" (Baeza, 2010, p. 58). The second thesis is that there has been poor state management for decision-making, such as communication problems at the central level and the delay in taking measures, such as the declaration of the state of siege, which the author calls "structural failure" (Baeza, 2010, p. 57) and which reflected a crisis of governability that produced a sort of social abandonment. The third thesis states that the population would have acted in the face of the earthquake with survival instinct and without trust in the authorities. The fourth thesis is formulated in terms in which the looters and those who defended themselves against them would have done so "in a very particular form of perception of the absence of social control over individual and collective human acts, to which is added a very peculiar devaluation of ethical-moral codes on a social scale" (Baeza, 2010, p. 61). However, it rejects the thesis of anomie. The fifth thesis is that individual social subjectivities gave way to a series of different motivations according to individual codes of conduct. Thus, the looting would have been produced by two motivations, one, by a feeling of imminent durable scarcity of essential goods, and two, by a feeling of unique opportunity to obtain goods for one's own use or for later commercialization. It finally recognizes that the looting took place at a transversal level at the level of the social classes. Rejects the idea of organized gangs. The sixth thesis is that issues of Chilean culture, such as solidarity, arose on the surface.

On the other hand, through a descriptive/exploratory study, Grandón and others, in approaching the study of the acts of looting and self-defense of looting by the citizens, separate "triggering factors" from "permanent factors", the former being the "emotional and cognitive impact of the event", the role of authority and the media (Grandón F. et al., 2014, p. 203). The "permanent factor" should be social inequality. "A capitalist economic system -the researchers point out- that encourages consumption and favors the acquisition of status by means of material symbols, is expressed in the desire to have and accumulate goods that, product of the same system, it is not possible to acquire. People can see through the media what they know is vetoed. In a society where the sensation of lack accompanies social life, when a phenomenon occurs that places the social structure in check, people take advantage of looting as a way of

\footnotetext{
${ }^{2}$ There was a mistaken belief on the part of the population that they were looting houses, fed in part by the information that the military gave to neighbors, reinforced by the simulation of attack they carried out
} 
obtaining goods in large quantities, even if they do not need them" (Grandón F. et al., 2014, p. 200). It is clear that looting and self-defense are due to forms of social violence triggered by situations of social conflict such as those caused by a disaster, and that they would respond to an underlying social conflict amplified by the neoliberal economic system that fosters social inequality, with phenomena such as polarization where the poor are the incarnation of the criminal and dangerous subject and who, motivated by the media, call to defend themselves against them and to protect private property. Looting would be an act of consumption to acquire that would allow them to identify with the ruling class. They point out that looting begins committed by individuals with criminal records, then people without antecedents are added, and that it would have a more ideological origin and as a form of "protest against the system" (Grandón F. et al., 2014). In addition, in a predictive way, they express: "As long as Chilean society does not increase its levels of equality, it is likely that social outbreaks such as those that occurred for the 27/F earthquake will continue to occur, particularly in the large urban cones where inequalities and their social consequences intensify" (Grandón F. et al., 2014, p. 203).

\section{2 | LOOTING IN THE SOCIAL EXPLOSION OF OCTOBER 2019}

According to official figures, and as for small and medium enterprises, out of 6,791 cadastral companies, "4,782 reported losses that imply significant deterioration in their infrastructure, equipment and merchandise," that is, $70 \%$, with the most conflictive zones being the Metropolitan Region (43.8\%), Valparaíso (14.6\%) and Biobío (10\%) (Gobierno de Chile, 2019). The data provided by the government's official website do not specify what types of "accidents" were provoked, and excludes in this count big business.

For its part, CIPER Chile points out that there are 196 looted supermarkets in the Metropolitan Region and some 326 at the national level (Albert, Miranda, \& Sepúlveda, 2019).

As of October 29, a national total of approximately 530 lootings had been recorded, concentrated mostly in the capital, Santiago, with 329 cases, approximately $60 \%$, with a total of 77 foreigners, representing $7 \%$ of the cases. A total of 1,516 people with criminal records were allegedly arrested, including 13 people with 180 previous arrests (Rivera, 2019).

The looting took place at the beginning of the conflict, without any police control. Many times the neighbors of the looted places, called insistently to the police, who never came(Albert et al., 2019). The looters even had the peace of mind of arriving in large means of transport (vans, trucks) to load the product of the looting. In some cases days passed, and the looting was repeated in the same places on different days. These issues reinforced the constitution of gangs to act in an organized way in the looting."The testimonies indicate that in the mobs that razed these premises there were no shouts of political slogans or anarchist stripes. With modesty, they recognize that the majority of those who intervened were neighbors who saw the opportunity to make an easy and unexpected profit" (Albert et al., 2019). Journalistic testimonies point out that some people said "Matilde doesn't know what she is stealing, but she does it anyway. "My neighbor told me it was an opportunity, so I came to accompany her" (...) She pushes a market cart full of "fierros"; construction materials she grabbed from a chain hardware store in southern Santiago de Chile" (Pardo, 2019); in some cases police officers (El Mostrador, 2019a) even participated, as well as people with criminal records (CNN Chile, 2019b).

It missed the null police presence in the looted places, despite repeated warnings from the population (Briones, 2019), even with reports that the police allowed looting, what people and a

with their exercises, in some points of the country (González-Muzzio, 2013; Guzmán, 2010b; Roca, 2016). They only created a collective paranoia. 
sector of the press called authorized looting (CNN Chile, 2019a; El Mostrador, 2019b; Flores, 2019). The police (Carabineros de Chile) excused themselves by pointing out that there were no personnel to arrest a mob. Hence, the neighbors of the place began to protect shopping malls, because they were the only services available to them. If they wore the "yellow vests" that distinguished them these days," Albert and others point out, "it was to replace the public security that the State did not provide" (Albert et al., 2019). In addition, the protection was not limited to preventing looting, but also the fires that occurred in supermarkets, after the looting, and in some cases, after the incident, the bodies of victims were found inside (Albert et al., 2019).

On 23 October, the looting was directed against certain objectives, such as that of the Hotel of the Principality of Asturias, commune of Providencia, in the Metropolitan Region, and that of the restaurant Casa Lucio, which were also destroyed and lined with spry slogans (Stuardo, 2019). Many other places near the "Plaza Italia" in Santiago (meeting place of the protests), the looted used it to make barricades (Peralta Sainz, 2019).

This could be considered as the first wave of looting, since a second wave, more violent, took place from the second week of November, whose starting point is the looting and burning of a Catholic church ("Parroquia de La Asunción"), in which furniture was extracted and used to build barricades (Veloso, 2019), and the highest point is registered on November 12, in the call for a National Strike by public employees, with looting and destruction of supermarkets, churches, bank branches, government buildings (Governorate of the city of Concepción; Regional Ministerial Secretary of Education of Bío-Bío; Cooperative of Carabineros in Antofagasta; Offices of Protection of Minors, of the Woman, Tourism, Original Town, the Gregorio de la Fuente Cultural Center of the city of La Serena), military locations (School of Engineers, San Antonio), Universities (University Pedro de Valdivia, seat Santiago), Courts (Court of Letters of Colina) among others (Delgado, 2019.); El Mostrador, 2019c; Monasterio, 2019; Redacción BBC, 2019; Redacción El Dínamo, 2019; Villarroel, 2019).

\section{6 | GENERAL ANALYSIS}

As for the comparison between the looting of $27 / \mathrm{F}$ and those of the outbreak of October 2019, can be seen in the following Table:

\begin{tabular}{|c|c|c|}
\hline Variable & $27 / F$ & Outbreaking october 2019 \\
\hline Looted Places & $\begin{array}{l}\text { supermarkets, warehouses, } \\
\text { shops, gas stations, banks. }\end{array}$ & $\begin{array}{l}\text { supermarkets, warehouses, } \\
\text { shops, gas stations, banks, } \\
\text { churchs, universities, } \\
\text { government buildings, military } \\
\text { buildings, judged. }\end{array}$ \\
\hline Looted items & $\begin{array}{l}\text { food, drinks, spirits, electronics, } \\
\text { clothing, appliances, furniture. }\end{array}$ & $\begin{array}{l}\text { food, drinks, spirits, electronics, } \\
\text { clothing, appliances, furniture, } \\
\text { religious objects. }\end{array}$ \\
\hline Destiny of looted objects & consume, sell. & consume, sell. \\
\hline Form of looting & groups, organized bands & groups, organized bands \\
\hline Looters place of belonging & from the same neighborhood & from the same neighborhood \\
\hline Type of looter & $\begin{array}{l}\text { person with and without a } \\
\text { criminal record }\end{array}$ & $\begin{array}{l}\text { person with and without a } \\
\text { criminal record }\end{array}$ \\
\hline Police attitude during looting & passive attitude, delay in arriving & $\begin{array}{l}\text { passive attitude, delay in } \\
\text { arriving, no presence }\end{array}$ \\
\hline $\begin{array}{l}\text { Attitude of the general } \\
\text { community }\end{array}$ & reprobation, sanction & reprobation/acceptance \\
\hline
\end{tabular}


In the systematization of Mac Ginty on the plunder, we have that they are given in both cases and in similar forms, the "precipitans". As for the "typology of looting" of the same author, it is graphical according to the following Table:

\begin{tabular}{|c|c|c|}
\hline Typology of looting & $27 / F$ & october 2019 \\
\hline Absolute need & 1 & 1 \\
\hline Contingency & 1 & 1 \\
\hline Wage augmentation & 0 & 0 \\
\hline Specialised market & 0 & 0 \\
\hline Trophy & 1 & 1 \\
\hline Celebratory & 0 & 0 \\
\hline Recreational & 0 & 0 \\
\hline Destructive & 0 & 0 \\
\hline Occupation & 0 & 0 \\
\hline Commodity & 1 & 1 \\
\hline Ethnic & 0 & 0 \\
\hline Area & 0 & 0 \\
\hline
\end{tabular}

In Table 1, the only differences between the civil disturbance of the October social outburst and the "natural" disaster of the 27/F earthquake are, with respect to the places of looting, since, in the civil disturbance unlike the earthquake, universities, churches, government and military buildings were additionally looted.

In Table 2 we can see that there is full agreement on the typological characteristics of both looting. Religious objects are not considered here but as "specialised market", but it is not the end of this typology, being an atypical "selective looting".

We have marked affirmatively in the typology of looting "trophy" for both cases of disaster. This, because the perception in both cases makes it seem that some looters behaved with a certain enjoyment, even in the looting during the earthquake 27/F ("I saw burlesque glances, people who were happy pushing a cart loaded with liquors or meat"), which is the enjoyment of the appropriate booty in the war for the winner of a battle.

For the rest, and in the earthquake 27/F, places like the store "La Polar" in the city of Concepción were looted and burned. During the looting and fires during the social explosion 2019 , this tent, although in the city of Osorno, was looted and burned. Same store, but in Santiago, and during the 2011 Student Movement protests in Chile, was burned. In 2010, the "La Polar case" arose before public opinion, consisting of a series of frauds by the store's top executives against its customers and a series of related institutions (AFP), which began to take shape in 2007. Such white-collar criminality was widely repudiated by the public (Baires \& Sullivan, 2011; Figueroa, 2015).

The looting during the social explosion of October 2019 has nuclear characteristics identical to those inferred and structured as such for looting in civil disturbances by scientific literature: the urban character; the type of looters, distributed between people with criminal 
records and those who did not, and with respect to these, perfectly socialized people; the type of objects looted, from articles of first necessity to other perfectly sumptuary, especially the latter; the places looted, among which were even reinforced in the looting of the October social explosion in "symbolic" places of protest and which represented the establishment in Chile, such as government buildings, military buildings, churches; the destination of the objects, which were for consumption, but above all, for sale; and the fact that the looters were fundamentally people from the neighbourhood; in terms of approval/approval, we have chosen to express it graphically in this way, because we could say that, in a very general observation, half the population rejected looting, but the other half at least cognitively shares the action.

The arguments that were generally put forward were that looting was a cost of the economic "looting" that financial groups have carried out in Chile, an act of rebellion, an expression of discontent and anger at the attitude of the country's political and economic elite, a form of punishment for the multinationals, a more criminal action against other systematic abuses produced by the neoliberal model that is inserted in Chile, for the fact of having the looted places safely contracted (Le Monde diplomatique, 2019; Pérez, 2019). Now, these appreciations suggest that the economic-social context makes it understandable that looting takes place, and, therefore, acceptable. This being so, this property of Quarantelli's and Dynes' analysis would be fulfilled, broadly speaking, in the facts.

\section{7 | DISCUSSION AND CONCLUSION}

\section{1 | OCTOBER 2019 LOOTING AS INDEX OF SOCIAL CHANGE IN CHILE}

According to what we have been developing, the starting point for the observation of the looting of the social explosion of October 2019 in Chile is the thesis of Quarantelli and Dynes, with some caveats. In the first place, the main object of analysis of the researchers (the looting in the U.S.A.), resembles the object of our analysis (the looting in Chile), since the bases laid for the construction of a social structure in Chile since 1974 were the neoliberals of the U.S.A. The main object of analysis of the researchers (the looting in the U.S.A.), resembles the object of our analysis (the looting in Chile), since the bases laid for the construction of a social structure in Chile since 1974 were the neoliberals of the U.S.A. The main object of analysis of the researchers (the looting in the U.S.A.), resembles the object of our analysis (the looting in Chile), since the bases laid for the construction of a social structure in Chile since 1974 were the neoliberals of the U.S.A. (Klein, 2008). In second place, the thesis of Quarantelli and Dynes explains, to our understanding, in a better way the looting and with greater probabilities of generalization that the expressive approaches, since when translating the looting in a data, a social indicator, it anticipates answers on problems of functioning of the system and/or structural by means of a more macrosocial reading.

The caveats have to do with four specific points.

The first of them affects the approach, as already explained earlier, that is, we understand that there is also in these looting the expressive element consisting of this acting-out but in its social character. The phallic root, or what is missing, would have to be found in the economic impoverishment caused by the Chilean social system, as we will detail later.

The second controversial point is the indicative character of Quarantelli and Dynes' approach, which seems to refer to the fact -when relating this idea to his 1968 work- that looting is used as a means of communicating the new property rules, or at least, their discussion. And, although his thesis does not refer to looting as an instrument of social change as other authors 
do (Prince, 1920; Sorokin, 2017), he flirts with this idea, since by understanding looting as a means of communicating new social rules about property, it is somehow and also an instrument to precipitate social change through this communication. Therefore, the indicative approach of the authors is a matter of emphasis of the approach.

The third point, which rather than being a discussion is an integration into the authors' vision, is an obvious but necessary prior distinction in qualifying the relationship between civil unrest and looting. Broadly and a priori we could say that not all civil unrest necessarily involves looting, which would lead us to understand that there are at least two kinds of civil unrest. One of these classes would have to be the expression of a social conflict that discusses the social system, and it is this that brings with it, the looting. The looting, in this context, would have to be an expression of critical levels of social conflict, and that is why it would be an index of social change, because it is then when they express the discussion of the right to property and the emergence of a legal status of that which competes with the current one. In our opinion, this kind of thing would be the looting of the social upsurge of October 2019.

Now, in Chile these critical levels are related to its current social system, which has originated a problem of economic and social inequality (Contreras, Otero, Díaz, \& Suárez, 2019; Martínez, Hodgson, Mullen, \& Timms, 2018; Méndez \& Otero, 2018; Olavarría-Gambi, 2012; Rotarou \& Sakellariou, 2017; Tejada, 2016), and with a phenomenon of transversal corruption of a majority sector of partisan politics (illegal financing of politics), of the company (collusion, fraud), ranging from economic "privileges" to economic criminality with significant degrees of impunity (Agostini, Willington, Lazcano, \& Saavedra, 2017; Bel \& Trillas, 2005; Borgias, 2018; Escobar-Farfán, Cardoza Cardoza, Vega, \& Cañas, 2017) ${ }^{3}$.

This has led to a feeling and attitude of discontent and indignation among the general population in the face of economic abuses, which keeps a popular social class under constant tension. In addition, a lumpenproletarial, lumpenprecarial and lumpenburgués type social byproduct has been generated (Franc, 1972; Marx, 2015; Standing, 2011), which has replicated in a speculative way the "white collar" criminality of the affluent classes, in a subaltern criminality of the middle class (computer frauds, swindles, misappropriation) and of the lower class (theft, crimes related to the use of bank cards, sale of drugs). There are studies on civil unrest in August 2011 in the UK that describe how the "looting" of state resources by political actors would have affected the health of the social body, suggesting a certain correlation between the antisocial attitude of political actors and the general public, such that the illegal behaviour of the British political system would have made people "potentially available" to participate in acts of illegality (Birch \& Allen, 2012). We could say that there is a certain reflection of the behaviour of politicians in the behaviour of the "plain state", a certain specular relation - and that even Machiavelli and Beccaria perceived in their time, between the image of the Prince and the subject, between the ferocity of the penal laws and the ferocity of the crimes in response, between the attitude of the rich and the attitude of the criminal as a correlate (Beccaria, 1764; Machiavelli, 2013)-: what is produced above, is reflected below. As it can be visualized, the problematic knot is, without a doubt, the property right.

\section{2 WHY THE PARTICULARITIES OF THE LOOTING IN THE EARTHQUAKE 27/F}

\footnotetext{
${ }^{3}$ This was the product of the social change that has occurred since 1989, when an economic model was structured and deepened, and the political and cultural model was replaced in Chile (Fischer, 2009; PérezAhumada, 2014; Rotarou\&Sakellariou, 2017).
} 
There are notable discrepancies with the analytical characteristics described in the literature for looting in "natural disasters," since, as expressed in the journalistic and academic literature account of the event under study and in Table 1, its characteristics differ completely from the "type" of looting of natural disaster exposed in disaster studies. Rather, it coincides with the characteristics of the "type" of looting in civil unrest.

We understand that it is not the analysis that is wrong in its hypothetical premises, but rather the phenomenon that responds to parameters different from the general premises considered by the analysis.

Chile has had several earthquakes in its history, and broadly speaking we can say that the looting was very marginal (regardless of the reasons for its reduced number), generally containing the characteristics described for looting in natural disasters (Cerro, 2010; El Mercurio de Valparaíso, 2005; El Mercurio S.A.P, 2015; Venegas, 2010). In fact, in the earthquake of Arica and Iquique in 2014, no looting was recorded, probably due to situational factors of prevention such as the rapid deployment of police forces, or geographical factors such as the fact that the earthquake was very focused (Solis, 2014). Therefore, we could not affirm in principle, that the "natural" disasters in Chile and as for the occurrence of looting have different particularities to those observed by the reviewed scientific literature, which leads us to conclude that the looting of the $27 / \mathrm{F}$ earthquake should be observed as an anomaly with respect to the looting in "natural disasters".

We explain this anomaly by situational and exotic factors.

As for the situational factors, and according to the testimonies here expressed, the null or extemporaneous police presence during all the time of the looting would be a factor that contributed positively to its occurrence.

The exotic factor would be conformed by objective and subjective conditions. The objective condition is related to the current Chilean social system, as we analyzed earlier. There is some relation with the "permanent factor" of Grandón and others in the looting of the 27/F. The subjective condition would be the perception of these phenomena by the population (Castillo, Miranda, \& Carrasco, 2012; Cociña, 2017).

The looting of the $27 / \mathrm{F}$ earthquake, by "resembling" civil unrest, was revealing critical levels of controversy over the current legal status of property, and thus already constituted an index of social change. They revealed the underlying social conflict that hindered the Chilean social system, and they did so, because, probably, the social energy of the former is as equivalent or greater in scale to that of the earthquake in its social impact. Thus, the problematic or highly dysfunctional social and economic conditions of the social system outbid, surpass, and impose themselves on the "natural" disaster of the earthquake.

Proof of this are similar phenomena of looting in "symbolic" places, such as the looting perpetrated in the "La Polar" Store, both in the 27/F and the looting of the social explosion of 2019, which is also related to the fire in the same Store in Santiago. There is a continuum, if you will, in antisocial behavior, whose precipitator is perhaps the cases of defrauding the executives of the Store, which is what produces a "permissible socio-cultural environment" for the looting.

On the other hand and also, the "trophy" character of the looting in the earthquake of $27 / \mathrm{F}$, and which is similar to the looting of the social explosion of October 2019 (which together with the fires of October 2019 and the protests of 2011), import a behavior close to looting in wars. So here there is an element to consider about the behavior of looters in their "expressive" forms, and that can be read as an expression of a continuous feeling of state of war, of being the opposite side in an asymmetrical war, and that at least in the looting, perceives a way to balance the balance. This would have to be studied later, which could be related to conflict theories. 
According to the previous observations, it would be urgent to visualize the problem by means of a moderate broad approach, because although it is accepted that in both cases there is a probability of looting, levels of differentiation are established according to their characteristics, depending on whether there are exotopic factors that condition the type of looting in "natural disasters", as is the case analyzed.

\subsection{THE POSSIBLE RELATIONSHIP BETWEEN LOOTING AND CRIMES AGAINST PROPERTY IN CHILE}

Hence, it is also possible to think that the critical problems of the Chilean social system are due to the increase in crimes against property, which have progressively increased over time, as shown in Table 3 and Figure 2.
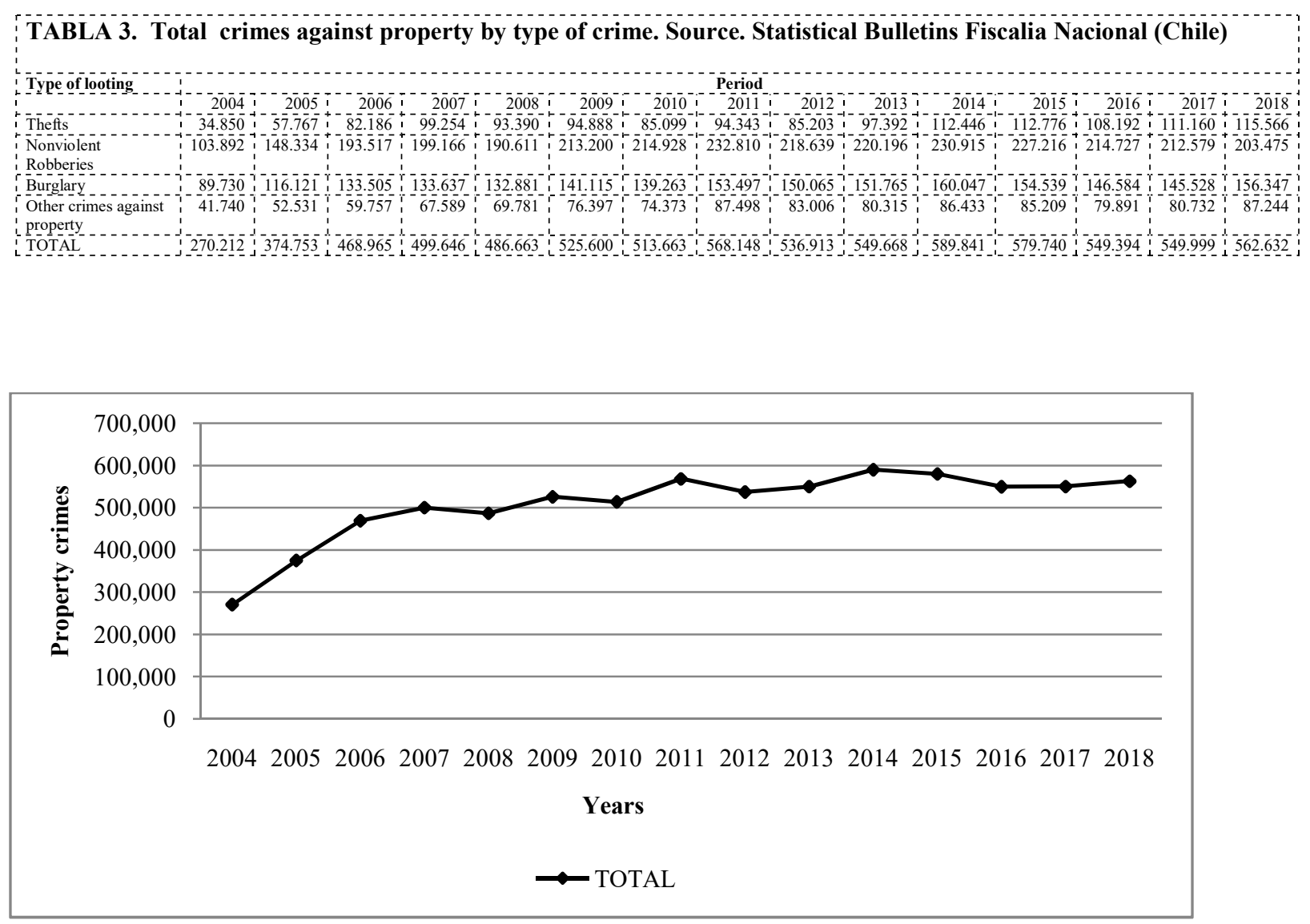

FIGURE 3 Total crimes against property (2004-2010)

There may even be a correlation between variables such as the progressive increase in crimes against property and the perception of political corruption and impunity for white-collar economic crimes; and between the progressive increase in crimes against property and social discontent.

This increase in crimes against property progressively during this period could, in our view, reflect a social conflict with property rights, with which it could be argued in an incipient way that a progressive increase in crimes against property could be an index of the existence of a discussion of property rights and their expression, as a norm and as a practice. This is because 
if looting constitutes the antisocial and criminal outbreak of civil unrest, which would represent a breakdown of a certain social continuity or stability, a high rate of crimes against property could be the antisocial equivalent of looting for a period of social continuity or stability. And so it could be said that very high rates of criminality against the property of the lower and middle classes that are sustained over time may also be another index of social change. In any case, and to validate the hypothesis, it would be necessary to empirically investigate in subsequent studies whether there is a correlation between high and sustained rates over time of crimes against the property of the lower and middle classes, and coexisting or later civil disturbances but close in time, between some possibilities of correlation of variables.

\section{4 | THE IDEAS OF THE LOOTING OF 27/F AS A "BLOODY CARNIVAL" AND AS AN "ACT OF CONSUMPTION" EXPOSED BY CHILEAN LITERATURE}

Baeza's idea of looting as a carnival coincides with the similar appreciation of Quarantelli \& Dynes that we highlighted at the time, and even of the press itself at the time of the looting (Guzmán, 2010a). But for us, it would not be a way to explain the phenomenon conveniently, being rather a literary comparison or a symbolic way to figure the event.

Regarding what Grandón and others, when affirming that looting would be an act of consumption, is somewhat attached to the idea of the greed thesis (Berdal, 2005; Mac Ginty, 2004). This idea is also expressed by the press and based on the comments of the persecuting authorities in Chile: "Do you know? Much of the theft responded to the logic of the purchase of liquidation. There were people who took 50 bottles of Coca-Cola, or empty jabas. What for? They thought like a liquidation: I don't need it, but it's cheap. Here it was free. Seen in this way, part of the destruction can be read as a huge cheap season in which Chileans - who according to many sociologists are no longer citizens but consumers - went mad" (Guzmán, 2010a).

However, we don't agree with this idea since, historically, looting has not only existed in consumer societies. What can be said a priori is that looting takes the form or reflects the social system and economic structure of its time, so looting in consumer societies will take the form of an act of consumption. Prostitution, for example, has always existed, but the social forms it adopts will depend on the social system in which it is inserted. The same thing would have to be thought of looting, and therefore that looting in Chile takes the form of consumption, in large part, by a neoliberal system to the U.S. type and even deeper than it, and therefore, the similarities with the collective attitude of a buying mass in a "Black Friday" with that of a looting in a consumer society like Chile. 


\section{REFERENCES}

Agostini, C. A., Willington, M., Lazcano, R., \& Saavedra, E. (2017). Predation and network based price discrimination in Chile. Telecommunications Policy, 41(9), 781-791. https://doi.org/10.1016/j.telpol.2017.04.006

Aguirre, B. E., \& Lane, D. (2019). Fraud in disaster: Rethinking the phases. International Journal of Disaster Risk Reduction, 39, 101232. https://doi.org/10.1016/j.ijdrr.2019.101232

Alarcón Corsi, H. (2010). Prisión preventiva, terremoto y saqueos: Comentario a las Sentencias de la Corte Suprema. Ius et Praxis, 16(2), 393-414. https://doi.org/10.4067/S071800122010000200014

Albert, C., Miranda, B., \& Sepúlveda, N. (2019, October 27). Crónica de cinco saqueos y nueve muertos: Estado de emergencia agudizó el abandono de la periferia [CIPER Chile]. Retrieved November 11, 2019, from https://ciperchile.cl/2019/10/27/cronica-de-cincosaqueos-y-nueve-muertos-estado-de-emergencia-agudizo-el-abandono-de-la-periferia/

Azam, J.-P., \& Hoeffler, A. (2002). Violence against Civilians in Civil Wars: Looting or Terror? Journal of Peace Research, 39(4), 461-485.

Baeza, M. A. (2010). Carnaval perverso: Terremoto + tsunami y saqueos en el Chile de 2010. Sociedad Hoy, (19), 53-69.

Baires, R., \& Sullivan, J. (2011, July 8). La Polar: Un mapa para entender cómo se fraguó y ejecutó el lema de "llegar y llevar" [CIPER Chile]. Retrieved December 1, 2019, from Investigación website: https://ciperchile.cl/2011/07/08/la-polar-un-mapa-para-entendercomo-se-fraguo-y-ejecuto-el-lema-de- $\%$ e2\%80\% $\%$ cllegar-y-llevar\%e $2 \% 80 \% 9 \mathrm{~d} /$

Beccaria, C. (1764). Dei delitti e delle pene. Retrieved from https://www.iberlibro.com/delittipene-MDCCLXIV-BECCARIA-Bonesana-Cesare/22714327423/bd

Bel, G., \& Trillas, F. (2005). Privatization, corporate control and regulatory reform: The case of Telefonica. Telecommunications Policy, 29(1), 25-51. https://doi.org/10.1016/j.telpol.2004.09.003

Bencsik, P. (2018). The non-financial costs of violent public disturbances: Emotional responses to the 2011 riots in England. Journal of Housing Economics, 40, 73-82. https://doi.org/10.1016/j.jhe.2018.03.002

Berdal, M. (2005). Beyond Greed and Grievance: And Not Too Soon ... A Review Essay. Review of International Studies, 31(4), 687-698.

Birch, S., \& Allen, N. (2012). 'There will be burning and a-looting tonight': The Social and Political Correlates of Law-breaking. The Political Quarterly, 83(1), 33-43. https://doi.org/10.1111/j.1467-923X.2012.02269.x

Black, W. K. (2005). The best way to rob a bank is to own one: How corporate executives and politicians looted the $S \& L$ industry (1st ed). Austin, Tex: University of Texas Press.

Bo, Z., Shaojie, O., Jianhua, Z., Hui, S., Geng, W., \& Ming, Z. (2015). An analysis of previous blackouts in the world: Lessons for China's power industry. Renewable and Sustainable Energy Reviews, 42, 1151-1163. https://doi.org/10.1016/j.rser.2014.10.069

Borgias, S. L. (2018). "Subsidizing the State:" The political ecology and legal geography of social movements in Chilean water governance. Geoforum, 95, 87-101. https://doi.org/10.1016/j.geoforum.2018.06.017

Briggs, D. (2012). The English Riots of 2011: A Summer of Discontent. Waterside Press.

Briones, N. (2019, October 25). Comerciante furiosa ante carabineros sentados mientras denunciaba saqueo de locales a una cuadra. Retrieved November 18, 2019, from BioBioChile_-La Red de Prensa Más Grande de Chile website: https://www.biobiochile.cl/noticias/nacional/regionmetropolitana/2019/10/25/comerciante-furiosa-ante-carabineros-sentados-mientrasdenunciaba-saqueo-de-locales-a-una-cuadra.shtml

Brown, B. L. V. (2019). Conflict or consensus? Re-examining crime and disaster. Jàmbá: Journal of Disaster Risk Studies, 11(1), 1-4. https://doi.org/10.4102/jamba.v11i1.744 
Bustamante, R. (2010). Terremoto en Chile: Rescates y saqueos en Concepción. http://www.bbc.co.uk/mundo/america_latina/2010/02/100228_1623_chile_saqueos_gtg .shtml

Carrasco-Jiménez, E. (2016, October 29). La abstención como un síntoma político. El Mostrador. Retrieved from http://www.elmostrador.cl/noticias/opinion/2016/11/18/laabstencion-como-un-sintoma/

Castillo, J. C., Miranda, D., \& Carrasco, D. (2012). Percepción de Desigualdad Económica en Chile: Medición, Diferencias y Determinantes. Psykhe, 21(1). https://doi.org/10.7764/psykhe.21.1.501

Cerro, F. A. (2010). Chillán después del Terremoto de 1939: Reconstrucción de una Ciudad, 1939-1950 (Memoria de grado, Universidad de Bío-Bío). Retrieved from http://repobib.ubiobio.cl/jspui/bitstream/123456789/1252/1/Cerro_Lagos_Fabian.pdf

CNN Chile. (2019a, October 25). "Absolutamente ilegal": Abogados desmienten que los "saqueos autorizados" tengan sustento legal. Retrieved November 18, 2019, from CNN Chile website: https://www.cnnchile.com/pais/saqueos-autorizados-ilegal_20191025/

CNN Chile. (2019b, November 15). 78\% de los detenidos por desórdenes y saqueos acumula al menos una detención previa. Retrieved November 18, 2019, from CNN Chile website: https://www.cnnchile.com/pais/78-de-los-detenidos-por-desordenes-y-saqueosacumula-al-menos-una-detencion-previa_20191115/

Cociña, M. (2017). Desiguales: Orígenes, cambios y desafios de la brecha social en Chile (S. Rucks, Ed.). Santiago: Programa de las Naciones Unidas para el Desarrollo (PNUD).

Conley, J. P., \& Wang, P. (2006). Crime and ethics. Journal of Urban Economics, 60(1), 107 123. https://doi.org/10.1016/j.jue.2006.02.006

Contreras, D., Otero, G., Díaz, J. D., \& Suárez, N. (2019). Inequality in social capital in Chile: Assessing the importance of network size and contacts' occupational prestige on status attainment. Social Networks, 58, 59-77. https://doi.org/10.1016/j.socnet.2019.02.002

Cull, R., Matesova, J., \& Shirley, M. (2002). Ownership and the Temptation to Loot: Evidence from Privatized Firms in the Czech Republic. Journal of Comparative Economics, 30(1), 1-24. https://doi.org/10.1006/jcec.2001.1754

Delgado, F. (2019, November 13). Barricadas y saqueos marcaron la madrugada de este miércoles en la capital. Retrieved November 13, 2019, from BioBioChile—La Red de Prensa Más Grande de Chile website: https://www.biobiochile.cl/noticias/nacional/regionmetropolitana/2019/11/13/barricadas-y-saqueos-marcaron-la-madrugada-de-estemiercoles-en-la-capital.shtml

El Mercurio de Valparaíso. (2005, March 31). Terremoto fue mucho peor. Retrieved November 19, 2019, from El Mercurio de Valparaíso website: http://www.mercuriovalpo.cl/prontus4_noticias/site/artic/20050331/pags/20050331033 533.html

El Mercurio S.A.P. (2015, September 17). Los peores terremotos en Chile desde 1900: Cinco se concentran después de 2000. Retrieved November 19, 2019, from Emol website: https://www.emol.com/noticias/Nacional/2015/09/17/750353/Sismos-en-los-ultimos100-anos.html

El Mostrador. (2019a, October 24). Decretaron prisión preventiva para gendarme y carabinero por saquear un supermercado. Retrieved November 18, 2019, from El Mostrador website: https://m.elmostrador.cl/noticias/pais/2019/10/24/decretaron-prisionpreventiva-para-gendarme-y-carabinero-por-saquear-un-supermercado/

El Mostrador. (2019b, October 24). Denuncia ciudadana acusa autorización de carabineros para saquear supermercado. Retrieved November 18, 2019, from El Mostrador website: https://www.elmostrador.cl/noticias/multimedia/2019/10/24/denuncia-ciudadana-acusaautorizacion-de-carabineros-a-saquear-supermercado/

El Mostrador. (2019c, November 11). Saqueos e incendio en el juzgado marcan agitada movilización nocturna en Colina. Retrieved November 18, 2019, from El Mostrador website: https://m.elmostrador.cl/noticias/multimedia/2019/11/11/saqueos-e-incendioen-el-juzgado-marcan-agitada-movilizacion-nocturna-en-colina/ 
Elm, E. von, Madrid, E., \& Urrútia, G. (2019). Chile: Civil unrest and Cochrane Colloquium cancelled. The Lancet, 394(10210), e35. https://doi.org/10.1016/S0140-6736(19)326789

Eschert, S., \& Simon, B. (2019). Respect and political disagreement: Can intergroup respect reduce the biased evaluation of outgroup arguments? PLOS ONE, 14(3), e0211556. https://doi.org/10.1371/journal.pone.0211556

Escobar-Farfán, M., Cardoza Cardoza, C., Vega, J., \& Cañas, M. (2017). Propuesta de modelo: Personalidad de marca en cadenas de farmacias en Chile. Suma de Negocios, 8(17), 4756. https://doi.org/10.1016/j.sumneg.2016.08.001

Espinoza, A. E., Osorio-Parraguez, P., \& Posada Quiroga, E. (2019). Preventing mental health risks in volunteers in disaster contexts: The case of the Villarrica Volcano eruption, Chile. International Journal of Disaster Risk Reduction, 34, 154-164. https://doi.org/10.1016/j.ijdrr.2018.11.013

Figueroa, J. P. (2015, October 22). La Polar: Las pruebas y las negociaciones a las puertas del juicio oral [CIPER Chile]. Retrieved December 1, 2019, from Investigación website: $\mathrm{https}$ ://ciperchile.cl/2015/10/22/la-polar-las-pruebas-y-las-negociaciones-a-las-puertasdel-juicio-oral/

Fischer, K. (2009). The Influence of Neoliberals in Chile before, during, and after Pinochet. In C. E. K. P. of E. and P. S. and the H. and P. of S. P. Mirowski, P. Mirowski, \& D. Plehwe (Eds.), The Road from Mont Pèlerin. Cambridge: Harvard University Press.

Flores, J. (2019, October 22). Los saqueos a supermercados "autorizados" por militares. Retrieved November 18, 2019, from BioBioChile—La Red de Prensa Más Grande de Chile website: https://www.biobiochile.cl/noticias/nacional/chile/2019/10/22/losrepetidos-saqueos-a-supermercados-autorizados-por-militares.shtml

Frailing, K. (2007). The Myth of a Disaster Myth: Potential Looting Should Be Part of Disaster Plans. Observer. Natural Hazard, 31(4), 3-4.

Frailing, K., \& Harper, D. W. (2017). Toward a criminology of disaster: What we know and what we need to find out. New York, NY: Palgrave Macmillan.

Franc, A. G. (1972). Lumpenburguesía: Lumpendesarrollo. Dependencia, clase y política en Latinoamérica.(Edición: Primera). Barcelona: Laia.

Fraser, B. (2019). Violent protests in Chile linked to health-care inequities. The Lancet, 394(10210), 1697-1698. https://doi.org/10.1016/S0140-6736(19)32720-5

Freud, A. (1968). Acting out. The International Journal of Psychoanalysis, 49(2-3), 165-170.

Gallego, J. (2018). Natural disasters and clientelism: The case of floods and landslides in Colombia. Electoral Studies, 55, 73-88. https://doi.org/10.1016/j.electstud.2018.08.001

Gobierno de Chile. (2019, November 4). Ministerio De Economía Cifra En Casi 6.800 Las Pymes Afectadas Por Saqueos, Incendios O Desmanes. Retrieved November 8, 2019, from Gobierno de Chile website: https://www.gob.cl/noticias/ministerio-de-economiacifra-en-casi-6800-las-pymes-afectadas-por-saqueos-incendios-o-desmanes/

González-Muzzio, C. (2013). El rol del lugar y el capital social en la resiliencia comunitaria posdesastre: Aproximaciones mediante un estudio de caso después del terremoto del 27/F. EURE (Santiago), 39(117), 25-48. https://doi.org/10.4067/S025071612013000200002

Grandón F., P., Acuña M., S., Briese M., C., Chovar M., P., Hernández F., A., \& Orellana E., F. (2014). Saqueos y autodefensa. Impacto social en chile post terremoto. Ajayu Órgano de Difusión Científica Del Departamento de Psicología UCBSP, 12(2), 187-206.

Guzmán, J. A. (2010a, June 29). Saqueadores: Ladrones de ocasión [CIPER Chile]. Retrieved November 11, 2019, from https://ciperchile.cl/2010/06/29/saqueadores-ladrones-deocasion/

Guzmán, J. A. (2010b, July 19). Saqueadores post terremoto II: La horda que nunca llegó a las casas [CIPER Chile]. Retrieved November 10, 2019, from https://ciperchile.cl/2010/07/19/saqueadores-post-terremoto-ii-la-horda-que-nuncallego-a-las-casas/ 
Hammer, E., Seifried, R., Franklin, K., \& Lauricella, A. (2018). Remote assessments of the archaeological heritage situation in Afghanistan. Journal of Cultural Heritage, 33, 125144. https://doi.org/10.1016/j.culher.2017.12.008

Harrison, C. G., \& Williams, P. R. (2016). A systems approach to natural disaster resilience. Simulation Modelling Practice and Theory, 65, 11-31. https://doi.org/10.1016/j.simpat.2016.02.008

Imperiale, A. J., \& Vanclay, F. (2019). Command-and-control, emergency powers, and the failure to observe United Nations disaster management principles following the 2009 L'Aquila earthquake. International Journal of Disaster Risk Reduction, 36, 101099. https://doi.org/10.1016/j.ijdrr.2019.101099

Johnson, I. M. (2005). The impact on libraries and archives in Iraq of war and looting in 2003A preliminary assessment of the damage and subsequent reconstruction efforts. The International Information \& Library Review, 37(3), 209-271. https://doi.org/10.1016/j.iilr.2005.07.005

Kaniasty, K. (2020). Social support, interpersonal, and community dynamics following disasters caused by natural hazards. Current Opinion in Psychology, 32, 105-109. https://doi.org/10.1016/j.copsyc.2019.07.026

Kinkopf, K. M., \& Beck, J. (2016). Bioarchaeological approaches to looting: A case study from Sudan. Journal of Archaeological Science: Reports, 10, 263-271. https://doi.org/10.1016/j.jasrep.2016.09.011

Klein, N. (2008). The Shock Doctrine: The Rise of Disaster Capitalism (Edición: 01). London: Penguin.

Kreps, G. A. (2001). Disasters, Sociology of. In N. J. Smelser \& P. B. Baltes (Eds.), International Encyclopedia of the Social \& Behavioral Sciences (pp. 3718-3721). https://doi.org/10.1016/B0-08-043076-7/01866-0

Lacan, J. (2004). Le séminaire, livre 10: L'angoisse. Paris: Le Seuil.

Lacan, J. (2005). Le Séminaire. Le Sinthome. Paris: Le Seuil.

Le Monde diplomatique. (2019, October 28). Comentarios sobre la generalización de la protesta en Chile. De la evasión a la rebelión. Retrieved November 19, 2019, from Le Monde diplomatique website: https://www.lemondediplomatique.cl/comentarios-sobre-lageneralizacion-de-la-protesta-en-chile-de-la-evasion-a-la.html

Leal, C. (2013, February 27). 2010-2013: Concepción y las cicatrices que quedan tras el terremoto del 27F. Retrieved November 10, 2019, from BioBioChile-La Red de Prensa Más Grande de Chile website: http://www.biobiochile.cl/noticias/2013/02/27/2010-2013-concepcion-y-las-cicatricesque-quedan-tras-el-terremoto-del-27f.shtml

Mac Ginty, R. (2004). Looting in the context of violent conflict: A conceptualisation and typology. Third World Quarterly, 25(5), 857-870. https://doi.org/10.1080/0143659042000231965

Machiavelli, N. (2013). Il Principe: Edizione del cinquecentennale (C. Donzelli \& G. Pedullà, Eds.). Roma: Donzelli.

Martínez, C. F., Hodgson, F., Mullen, C., \& Timms, P. (2018). Creating inequality in accessibility: The relationships between public transport and social housing policy in deprived areas of Santiago de Chile. Journal of Transport Geography, 67, 102-109. https://doi.org/10.1016/j.jtrangeo.2017.09.006

Marx, K. (2015). Las luchas de clases en Francia de 1848 a 1850. Madrid: Fundación Federico Engels.

Méndez, M. L., \& Otero, G. (2018). Neighbourhood conflicts, socio-spatial inequalities, and residential stigmatisation in Santiago, Chile. Cities, 74, 75-82. https://doi.org/10.1016/j.cities.2017.11.005

Monasterio, F. (2019, November 12). La peor jornada de violencia desde el inicio del estallido social. Retrieved November 13, 2019, from Pauta website: https://www.pauta.cl/politica/la-violencia-que-el-12-de-noviembre-se-tomo-el-pais

Moreno, J., Lara, A., \& Torres, M. (2019). Community resilience in response to the 2010 tsunami in Chile: The survival of a small-scale fishing community. International 
Journal of Disaster Risk Reduction, 33, 376-384.

https://doi.org/10.1016/j.ijdrr.2018.10.024

Moreno, J., \& Shaw, D. (2019). Community resilience to power outages after disaster: A case study of the 2010 Chile earthquake and tsunami. International Journal of Disaster Risk Reduction, 34, 448-458. https://doi.org/10.1016/j.ijdrr.2018.12.016

Mueller, J. (2003). Policing the Remnants of War. Journal of Peace Research, 40(5), 507-518. https://doi.org/10.1177/00223433030405001

Muhlin, G. L., Cohen, P., Struening, E. L., Genevie, L. E., Kaplan, S. R., \& Peck, H. B. (1981). Behavioral epidemiology and social area analysis: The study of blackout looting. Evaluation and Program Planning, 4(1), 35-42. https://doi.org/10.1016/01497189(81)90052-5

Olavarría-Gambi, M. (2012). Beyond income: Analysis of inequality in Chile from 1980 to 2000 decades. Tékhne, 10(1), 39-53. https://doi.org/10.1016/S1645-9911(12)70005-1

Ozguc, U. (2019). Borders, Detention, and the Disruptive Power of the Noisy-Subject. International Political Sociology, 1-17. https://doi.org/10.1093/ips/olz026

Pardo, D. (2019, October 23). Los saqueos que se registraron en Santiago de Chile en medio de las masivas protestas. $B B C$ News Mundo. Retrieved from https://www.bbc.com/mundo/noticias-america-latina-50148049

Peralta Sainz, A. (2019, November 7). Lucio Torres, "El Rey de Plaza Italia": "Nos sacaban los televisores y los usaban para prender barricadas afuera." Retrieved November 13, 2019, from The Clinic website: https://www.theclinic.cl/2019/11/07/lucio-torres-el-rey-deplaza-italia-nos-sacaban-los-televisores-y-los-usaban-para-prender-barricadas-afuera/

Peretz, H. (2014). Les méthodes en sociologie: L'observation. Paris: La Découverte.

Pérez, G. (2019, October 21). Compradores apoyan las demandas, pero no aprueban saqueos de supermercados. Retrieved November 19, 2019, from El Rancagüino website: https://www.elrancaguino.cl/2019/10/21/compradores-apoyan-las-demandas-pero-noaprueban-saqueos-de-supermercados/

Pérez-Ahumada, P. (2014). Class consciousness in a mature neoliberal society: Evidence from Chile. Research in Social Stratification and Mobility, 38, 57-75. https://doi.org/10.1016/j.rssm.2014.06.002

Perry, R. W. (2007). What Is a Disaster? In H. Rodríguez, E. L. Quarantelli, \& R. R. Dynes (Eds.), Handbook of Disaster Research (pp. 1-15). https://doi.org/10.1007/978-0-38732353-4_1

Phillips, B. D. (2015). Chapter 20-Therapeutic Communities in the Context of Disaster. In J. F. Shroder, A. E. Collins, S. Jones, B. Manyena, \& J. Jayawickrama (Eds.), Hazards, Risks and Disasters in Society (pp. 353-371). https://doi.org/10.1016/B978-0-12396451-9.00020-2

Pizzo, S., Fricker, M., \& Muolo, P. (2015). Inside Job: The Looting of America's Savings and Loans. Open Road Media.

Prince, S. H. (1920). Catastrophe and social change: Based upon a sociological study of the Halifax disaster. Retrieved from http://archive.org/details/catastrophesocia00prinuoft

Quarantelli, E. (1994). Looting and Antisocial Behavior in Disasters. Retrieved from http://udspace.udel.edu/handle/19716/590

Quarantelli, E. (2007). The Myth and the Realities: Keeping the "Looting" Myth in Perspective. Observer. Natural Hazard, 31(4), 2-3.

Quarantelli, E., \& Dynes, R. R. (1968). Looting in Civil Disorders: An Index of Social Change. American Behavioral Scientist, 11(4), 7-10. https://doi.org/10.1177/000276426801100403

Quarantelli, E., \& Dynes, R. R. (1977). Response to Social Crisis and Disaster. Annual Review of Sociology, 3(1), 23-49. https://doi.org/10.1146/annurev.so.03.080177.000323

Quarantelli, E. L. (2008). Conventional Beliefs and Counterintuitive Realities. Retrieved from http://udspace.udel.edu/handle/19716/4242

Quarantelli, E. L., \& Dynes, R. R. (1969). Dissensus and consensus in community emergencies: Patterns of looting and property norms. Il Politico, 34(2), 276-291. Retrieved from JSTOR. 
Quarantelli, E. L., \& Dynes, R. R. (1970). Property Norms and Looting: Their Patterns in Community Crises. Phylon (1960-), 31(2), 168-182. https://doi.org/10.2307/273722

Redacción BBC. (2019, November 13). Superintendente de bomberos de Santiago: "Estamos descolocados por tanta quema, tanto saqueo." BBC News Mundo. Retrieved from https://www.bbc.com/mundo/noticias-america-latina-50409354

Redacción BBC Mundo. (2010, March 7). Terremoto en Chile: Testimonios en primera persona. Retrieved November 19, 2019, from BBC News Mundo website: https://www.bbc.com/mundo/america_latina/2010/02/100227_chile_terremoto_testimo nios

Redacción El Dínamo. (2019, November 12). Saqueos e incendios a lo largo del país en paro nacional de Unidad Social. Retrieved November 13, 2019, from Https://www.facebook.com/el.dinamo website: https://www.eldinamo.cl/nacional/2019/11/12/saqueos-e-incendios-a-lo-largo-del-paisen-paro-nacional-de-unidad-social-2/

Rivera, V. (2019, October 26). El mapa de los 195 saqueos en Santiago que dejaron 1.156 personas detenidas. Retrieved November 12, 2019, from La Tercera website: https://www.latercera.com/nacional/noticia/mapa-los-195-saqueos-santiago-dejaron-1156-personas-detenidas/878670/

Roca, A. (2016). Do Medo do Terremoto ao Medo Dos Outros. Hucitec.

Rotarou, E. S., \& Sakellariou, D. (2017). Neoliberal reforms in health systems and the construction of long-lasting inequalities in health care: A case study from Chile. Health Policy, 121(5), 495-503. https://doi.org/10.1016/j.healthpol.2017.03.005

Rovira Kaltwasser, C. (2019, October 23). If Piñera wants to wage war in Chile he should fight the real enemy: Inequality. The Guardian. Retrieved from https://www.theguardian.com/commentisfree/2019/oct/23/chile-protest-war-pinerainequality

Ruiz, N. O. (2019). Cacerolazo: Emociones y memoria en el movimiento estudiantil 2011. Polis. Revista Latinoamericana, (53). Retrieved from http://journals.openedition.org/polis/17465

Salazar, G. (2019, October 27). El «reventón social» en Chile: Una mirada histórica [CIPER Chile]. Retrieved November 11, 2019, from https://ciperchile.cl/2019/10/27/elreventon-social-en-chile-una-mirada-historica/

Sanzana Calvet, M. (2010). Desastre natural y acción colectiva de los sectores populares en Chile. XI(28), 145-157.

Silver, A., \& Grek-Martin, J. (2015). "Now we understand what community really means": Reconceptualizing the role of sense of place in the disaster recovery process. Journal of Environmental Psychology, 42, 32-41. https://doi.org/10.1016/j.jenvp.2015.01.004

Solis, C. (2014, April 2). Carabineros asegura que no hubo saqueos tras terremoto. Retrieved November 19, 2019, from 24Horas.cl website: https://www.24horas.cl/nacional/carabineros-asegura-que-no-hubo-saqueos-trasterremoto-1160307

Sorokin, P. A. (2017). Man and Society in Calamity. Retrieved from http://www.vlebooks.com/vleweb/product/openreader?id=none\&isbn=9781351507547

Standing, G. (2011). The Precariat: The New Dangerous Class. London: A\&C Black.

Stuardo, M. (2019, October 23). "Se descontroló todo, nos rompieron todo": Saquean hotel Principado de Asturias en Providencia. Retrieved November 13, 2019, from BioBioChile_-La Red de Prensa Más Grande de Chile website: https://www.biobiochile.cl/noticias/nacional/region-metropolitana/2019/10/23/sedescontrolo-todo-nos-rompieron-todo-saquean-hotel-principado-de-asturias-enprovidencia.shtml

Tapete, D., Cigna, F., \& Donoghue, D. N. M. (2016). 'Looting marks' in space-borne SAR imagery: Measuring rates of archaeological looting in Apamea (Syria) with TerraSARX Staring Spotlight. Remote Sensing of Environment, 178, 42-58. https://doi.org/10.1016/j.rse.2016.02.055 
Tejada, M. M. (2016). Lifetime inequality measures for an emerging economy: The case of Chile. Labour Economics, 42, 1-15. https://doi.org/10.1016/j.labeco.2016.06.002

Tidball, K. G., \& Aktipis, A. (2018). Feedback enhances greening during disaster recovery: A model of social and ecological processes in neighborhood scale investment. Urban Forestry \& Urban Greening, 34, 269-280. https://doi.org/10.1016/j.ufug.2018.07.005

Veloso, L. (2019, November 8). Saqueadores ingresan a Iglesia en Santiago y usan bancas, confesionarios e imágenes como barricada. Retrieved November 13, 2019, from BioBioChile_-La Red de Prensa Más Grande de Chile website: https://www.biobiochile.cl/noticias/nacional/chile/2019/11/08/saqueadores-ingresan-aiglesia-santago-bancas-confesionario.shtml

Venegas, C. (2010). Tres veces de pie [Revista Nos]. Retrieved November 19, 2019, from http://www.revistanos.cl/2010/04/tres-veces-de-pie/

Villarroel, M. J. (2019, November 11). Formalizan a 5 acusados de incendio y saqueo a sede de UPV: Uno de ellos quedó en prisión preventiva. Retrieved November 18, 2019, from BioBioChile - La Red de Prensa Más Grande de Chile website: https://www.biobiochile.cl/noticias/nacional/regionmetropolitana/2019/11/11/formalizan-a-5-acusados-de-incendio-y-saqueo-a-sede-deupv-uno-de-ellos-quedo-en-prision-preventiva.shtml

Warren, M. (2010, February 28). Heró́smo y saqueos tras terremoto en Chile. Retrieved November 10, 2019, from El Nuevo Herald website: https://www.elnuevoherald.com/ultimas-noticias/article2003456.html 